\title{
Maintenance of cytomegalovirus-specific CD4pos T-cell response in rheumatoid arthritis patients receiving anti-tumor necrosis factor treatments
}

\author{
Jean-Luc Davignon*1,2, Jean-Frédéric Boyer1,2, Bénédicte Jamard², Delphine Nigon 1,2, Arnaud Constantin2,3 and \\ Alain Cantagrel1,2
}

\begin{abstract}
Introduction: Anti-tumor necrosis factor (TNF)-a biotherapies have considerably changed the treatment of rheumatoid arthritis (RA). However, serious infections are a major concern in patients with rheumatic diseases treated with anti-TNF-a. Little is known about viral, especially latent, infections in anti-TNF-a treatments. Infections by cytomegalovirus (CMV), a $\beta$-herpes virus, are frequent and induce a strong CD4pos T-cell immunity, which participates in the control of infection. We thus have chosen to analyze the CD4pos T-cell response to CMV antigens as a model of antiviral response in RA patients treated with anti-TNF-a. CD28 expression was evaluated.

Methods: We have measured the CD4pos response to CMV antigens in RA patients, before and after initiation of treatment with an anti-TNF-a agent. The intracellular production of interferon (IFN) $-\gamma$ in total and CD28neg CD4pos T cells in response to CMV antigens (Ags) was evaluated with flow cytometry. The proliferation of total CD4pos $T$ cells in the presence of $\mathrm{CMV}$ antigens was measured with ${ }^{3} \mathrm{H}$-thymidine incorporation.

Results: Anti-TNF-a treatments impaired neither the anti-CD4pos anti-CMV IFN- $\gamma$ response nor the proliferative response in patients. The percentage of $\mathrm{CD} 28^{\text {neg }} \mathrm{CD} 4$ pos cells remained constant.

Conclusions: Our data suggest that the CD4pos T-cell response against CMV is not altered by anti-TNF-a treatments and that infection remains controlled in treated RA patients latently infected with CMV. Our observation brings new insight into the current knowledge of the risks of infection in patients treated with anti-TNF-a biotherapies.
\end{abstract}

\section{Introduction}

Current therapies for RA are aimed at inhibiting inflammatory cytokines, especially tumor necrosis factor (TNF)- $\alpha$ biotherapies, such as antibodies (infliximab, adalimumab) and soluble receptor (etanercept) specific for TNF. These three commercially available TNF antagonists have been tested in established and in early diseases. They effectively improved disease activity and significantly slowed radiologic deterioration [1,2]. However, serious infections are a major concern in patients with rheumatic diseases, and inhibition of TNF- $\alpha$ increases the risk of serious and benign infections [3]. The role played by TNF- $\alpha$ in the body's defense against bacterial

*Correspondence: jean-luc.davignon@inserm.fr

1 JE 2510, University Paul Sabatier Toulouse III. France, IFR 150, CPTP, Bâtiment C, CHU Purpan, 1, place Baylac, 31300 Toulouse, France

Full list of author information is available at the end of the article and viral invasion is multiple: recruitment of neutrophils, eosinophils, and macrophages; release of cytokines and local chemokines; attraction and activation of phagocytes; increased T-cell adhesion; enhanced antigen presentation; and recruitment and proliferation of $\mathrm{T}$ and $\mathrm{B}$ cells [4]. Moreover, TNF- $\alpha$ is also involved in the formation and sustainment of Mycobacterium granulomatous lesions [5]. Neutralization of TNF- $\alpha$ for treating rheumatic diseases increases the risk of reactivation and outbreak of tuberculosis and other opportunistic infections [6,7]. A decrease of the tuberculosis-specific CD4pos Tcell response in patients treated with anti-TNF was found [8]. In addition, anti-TNF treatment induced a reduction in effector memory CD8pos $\mathrm{T}$ cells specific for mycobacteria [9].

In contrast, less is known about viral infections. Herpesviruses can persist in patients in a latent state and be 
reactivated under situations of immunosuppression. Although cases of lymphoproliferative disorders have been reported in RA, the role of TNF- $\alpha$ antagonists in Epstein-Barr virus (EBV)-related lymphomas is not clear $[3,10,11]$. Conversely, inflammation, a hallmark of RA, might be associated with the risk of lymphoma [12]. Regarding EBV infections, data are rather reassuring. In a recent study, no impairment of the anti-EBV CD8pos Tcell response was found in patients treated with anti-TNF, and the EBV viral load was not increased [13]. However, regarding varicella zoster virus, another herpesvirus, a recent publication suggested that anti-TNF- $\alpha$ antibodies could be associated with increased risk of reactivation, responsible for an increased rate of herpes zoster events in patients treated with these biologic agents [14].

Cytomegalovirus (CMV) is a member of the $\beta$-herpesvirus subfamily, which infects $50 \%$ to $60 \%$ of the European population. Primary infections are mostly unnoticed. However, the virus reactivates from latent infections on immunosuppression, leading to graft rejection and severe pathology, such as pneumonitis in bone marrow transplantation, colitis, and retinitis in AIDS [15]. CD4pos and CD8pos T-cell responses against CMV have been studied by using peptides, recombinant proteins, or lysates of infected cells [16-19]. Frequencies of CMV-specific CD4pos and CD8pos T-cells have been shown to be extremely high in immunocompetent persons [17], and to be maintained throughout life [20]. Contributions of CD4pos and CD8pos $\mathrm{T}$ cells have been demonstrated both in vitro [21,22] and in vivo, $[23,24]$.

Although CD4pos $\mathrm{T}$ cells possess their own capacity to inhibit CMV replication [21,22,25], they also contribute to the differentiation and maintenance of CMV-specific CD8pos T cells [23]. Moreover, anti-CMV specific effectors are increased in CD28neg CD4pos $\mathrm{T}$ cells $[17,26]$, a population that is expanded in RA, because of TNF- $\alpha$ $[27,28]$. TNF- $\alpha$ has been demonstrated not only to play a prominent role in RA but also to diminish the intensity of the T-cell response [29]. Moreover, anergy of T cells was observed in RA patients [30]. Therefore, the outcome of the anti-CMV CD4pos T-cell response in RA patients treated with anti-TNF- $\alpha$ is of interest.

Case reports have mentioned the reactivation of CMV in anti-TNF-treated patients [3]. It is thus important to know more precisely the persistence of anti-CMV memory CD4pos $\mathrm{T}$ cells in RA. The high proportion of CMVseropositive individuals and the high frequencies of CMV-specific $\mathrm{T}$ cells allow the follow-up of the $\mathrm{Ag}$ response ex vivo $[17,18]$. We thus have chosen to test the anti-CMV CD4pos T-cell response as a model for the study of the antiviral response in RA patients whose TNF- $\alpha$ is neutralized with anti-TNF. We previously showed that TNF- $\alpha$ participates in the control of infec- tion [25]. Because neutralization of TNF- $\alpha$ may alter the control of CMV, we thus measured the CD4pos T-cell response in RA patients treated with anti-TNF.

Because IFN- $\gamma$ produced by CD4pos $\mathrm{T}$ cells is important in the control of CMV in vitro [25] and in vivo [21], we tested the intracellular production of IFN- $\gamma$ in $\mathrm{CD} 4$ pos $\mathrm{T}$ cells in response to total CMV Ags in patients with RA, before and after initiation of treatment with an anti-TNF$\alpha$ agent. Specific proliferation in response to CMV Ags also was investigated. Our data show that anti-TNF treatments do not impair the CD4pos anti-CMV response and suggest that CMV infection remains controlled in treated RA patients latently infected with CMV.

\section{Materials and methods \\ Patients}

Patients were included in this study according to several criteria: RA diagnosed according to the 1987 ACR criteria, with active disease, eligible for a first anti-TNF therapy after failure of at least one previous diseasemodifying antirheumatic drug (DMARD). Active disease was defined on a Disease Activity Score, assessed by using 28-joint counts (DAS28), above 3.2 [31]. Other associated treatments (DMARD, steroids, NSAIDs) had to be stable for 6 months before inclusion and remain stable during the study.

Patients were tested for CMV serologic status at the time of inclusion. Blood samples were drawn from CMVseropositive patients before the beginning of anti-TNF- $\alpha$ treatment (day 0 ) and at weeks 6 and 12 after the beginning of treatment. Blood samples were drawn from $\mathrm{CMV}$-seronegative patients, only once (on day 0 ) to evaluate the background response of unimmunized subjects.

Patients were receiving either TNF- $\alpha$ soluble receptor (Etanercept) or antibodies (either Infliximab or Adalimumab), according to physicians' choice. Disease Activity Score (DAS 28) was calculated at every visit, and patients' response to treatment was evaluated at week 12 according to EULAR response criteria [32].

The present study was performed with approval of the local ethics committee (CPP Toulouse II), and informed consent was obtained from all participants.

\section{Methods}

\section{Separation and preservation of cells}

Blood was collected in citrate tubes, and peripheral blood mononuclear cells (PBMCs) were isolated with Lymphoprep gradient separation (Abcys Biology, Paris, France). Cells were then resuspended in 10\% DMSO-40\% SVF-containing medium and kept frozen in liquid nitrogen.

\section{Antibodies and reagents (preparation of CMV Ag)}

Anti-CD4-PE-Cy5 was purchased from eBiosciences (CliniSciences, Montrouge, France), and anti-CD28-PE 
and anti-IFN- $\gamma$-FITC were purchased from PharMingen (BD PharMingen, Le Pont de Claix, France). Brefeldin A was purchased from Sigma (Sigma-Aldrich, Saint-Quentin Fallavier France).

CMV total Ags were prepared as described in [16]. In brief, MRC5 cells were infected with the Towne strain of $\mathrm{CMV}$ at the MOI of 0.1. Cells were harvested 6 days later, washed 3 times in PBS, and lyzed by sonication. The sonicate was centrifuged, and the pellet resuspended in PBS, aliquoted, and stored at $-80^{\circ} \mathrm{C}$. Control $\mathrm{Ag}$ was prepared in parallel by using the same protocol, except that cells were uninfected.

\section{Flow cytometry and intracellular IFN- $\gamma$ assay}

Flow cytometry for the detection of intracellular IFN- $\gamma$ was performed as described by Vaz-Santiago et al. [16]. In brief, cells $\left(2 \times 10^{6}\right.$ in $200 \mu \mathrm{l}$ RPMI medium, 10\% SVF) were incubated with the appropriate amount of CMV Ags or control Ags for $4 \mathrm{~h}$. Then Brefeldin A $(4 \mathrm{mg} / \mathrm{ml})$ was added for $12 \mathrm{~h}$ in $1.6 \mathrm{ml}$, and cells were left at $37^{\circ} \mathrm{C}$ under a humidified $5 \% \mathrm{CO}_{2}$ atmosphere. Cells were then washed and stained for surface markers (CD28 and CD4), and then permeabilized by using the Becton Dickinson intracellular cytokine kit. Cells were then stained for intracellular IFN- $\gamma$.

\section{Proliferation assay}

PBMCs $\left(2 \times 10^{5}\right)$ were incubated in 96-well $(200 \mu \mathrm{l}) \mathrm{U}$ bottomed plates in RPMI-HS (AB CMV seronegative serum) in triplicate, in the presence of either CMV Ags or control Ags. On day 5, cultures were pulsed overnight with $\left[{ }^{3} \mathrm{H}\right]$ thymidine $\left(\left[{ }^{3} \mathrm{H}\right] \mathrm{TdR}\right.$; Amersham $)(1 \mu \mathrm{Ci} /$ well $)$. The $\left[{ }^{3} \mathrm{H}\right] \mathrm{TdR}$ incorporation was determined in a beta counter and expressed as the mean of triplicates. The Stimulation Index was calculated as the ratio of means obtained by using CMV Ags over those obtained by using control Ags.

\section{Statistics}

After the Shapiro-Francia normality test was applied, the data were analyzed by using nonparametric tests: the Mann-Whitney two-sample statistic, the Kruskal-Wallis (several-sample statistic), and the Wilcoxon matchedpairs signed-ranks test.

Statistical analyses were performed by using Stata Statistical Software (Intercooled Stata 8.2; Stata Corporation, College Station, TX, USA).

\section{Results}

\section{Characteristics of patients}

Twenty-five patients (23 women and two men) median (extremes) age 55 years (31 to 81 years) years; disease duration, 12 years ( 2 to 26 years) were included in the present study (Table 1 ). CMV serologic status was positive in 17 patients but negative in eight patients. All seropositive patients had IgG but no IgM specific for CMV. In
CMV-positive patients, the anti-TNF agent was added to methotrexate in nine, and to leflunomide in one, whereas it was prescribed as monotherapy in seven patients. At week 12, $11(64.7 \%)$ patients were considered good or moderate responders $(\mathrm{R})$, whereas $6(35.3 \%)$ were considered nonresponders (NRs), according to EULAR response criteria. The overall clinical response $(64.7 \%)$ observed after a 12-week period is in agreement with that reported in other studies [33].

\section{Intracellular IFN- $\gamma$ response in CD4pos from RA patients treated with anti-TNF}

The intracellular CD4pos response was assessed in both $\mathrm{CMV}$-seropositive and -seronegative patients. Figure 1a,b shows the percentage of CD4pos T cells expressing IFN- $\gamma$ in response to CMV Ags when tested in two patients seropositive for $\mathrm{CMV}$ in three consecutive samples (onset of anti-TNF treatment, week 6, and week 12). As expected, the response for CMV Ags was undetectable in seronegative patients (Figure 1c).

The IFN- $\gamma$ response to CMV Ags (Figure 2a) was detectable in all seropositive patients and was always above that observed in the presence of control Ags (data not shown). The mean percentage of the response to CMV Ags was $0.35 \%$, whereas the response to control Ags was less than $0.02 \%$. No statistical significant modification of the response towards CMV Ags was noted after 6 weeks $(0.43 \%)$ or 12 weeks $(0.49 \%)$ of treatment with the TNF blocker. When responders and nonresponders to anti-TNF treatment were compared, no significant difference was observed at any of the time points (data not shown). The same is true when comparing the response to CMV Ags in patients treated with a monoclonal antibody or the soluble receptor of TNF.

\section{Proliferation response to CMV Ags}

Proliferation in the presence of CMV Ags was assessed in both CMV-seropositive and -seronegative patients. As expected, seronegative patients did not respond to CMV Ags (data not shown). However, CMV-seropositive patients did respond to CMV Ags, but the response did not significantly vary over the time of exposure to antiTNF- $\alpha$ (Figure 2b). Similar to what was observed with IFN- $\gamma$ production, we were not able to find significant patterns in patients classified clinically as responders and nonresponders at week 12 or in patients treated with a monoclonal antibody and those treated with a soluble receptor of TNF.

\section{High percentages of IFN- $\gamma$-secreting cells within the CD28 neg CD4pos population in response to CMV Ags}

It has been reported that the $\mathrm{CD} 28^{\text {neg }}$ population is enriched in RA patients [29] and that this phenotype is due to TNF- $\alpha[28,34]$. We thus evaluated whether the 
Table 1: Characteristics of patients

\begin{tabular}{|c|c|c|c|c|c|c|}
\hline Patients & RA (years) & Anti-TNF & Steroids & DMARDS & CMV serology status & Clinical response \\
\hline 1 & 26 & $A D A$ & PRED 5 & None & + & $\mathrm{NR}$ \\
\hline 2 & 2 & ETA & PRED 20 & MTX & + & $\mathrm{R}$ \\
\hline 3 & 12 & ETA & PRED 5 & MTX & + & NR \\
\hline 4 & 17 & INF & None & None & + & $\mathrm{R}$ \\
\hline 5 & 5 & ETA & PRED 20 & None & + & $\mathrm{R}$ \\
\hline 6 & 4 & ETA & PRED 10 & None & + & $\mathrm{R}$ \\
\hline 7 & 23 & ETA & None & MTX & + & $\mathrm{R}$ \\
\hline 8 & 7 & INF & PRED 10 & None & + & $\mathrm{R}$ \\
\hline 9 & 26 & INF & PRED 7 & None & + & $\mathrm{R}$ \\
\hline 10 & 20 & ETA & PRED 5 & MTX & + & NR \\
\hline 11 & 14 & INF & PRED 10 & MTX & + & $\mathrm{R}$ \\
\hline 12 & 20 & $\mathrm{ADA}$ & PRED 10 & MTX & + & $\mathrm{R}$ \\
\hline 13 & 3 & $\mathrm{ADA}$ & None & Leflunomide & + & $\mathrm{R}$ \\
\hline 14 & 13 & INF & PRED 10 & None & + & $\mathrm{R}$ \\
\hline 15 & 2 & ETA & None & MTX & + & $\mathrm{NR}$ \\
\hline 16 & 12 & INF & None & MTX & + & NR \\
\hline 17 & 12 & INF & PRED 10 & MTX & + & NR \\
\hline 18 & 8 & INF & None & MTX & - & $\mathrm{R}$ \\
\hline 19 & 17 & ETA & PRED 20 & MTX & - & $\mathrm{R}$ \\
\hline 20 & 4 & INF & None & AlloChrysine & - & $\mathrm{R}$ \\
\hline 21 & 11 & ETA & PRED 5 & MTX & - & NR \\
\hline 22 & 15 & ETA & None & Leflunomide & - & NR \\
\hline 23 & 9 & ETA & None & MTX & - & $\mathrm{R}$ \\
\hline 24 & 20 & $\mathrm{ADA}$ & PRED 10 & None & - & $\mathrm{R}$ \\
\hline 25 & 13 & $\mathrm{ADA}$ & None & MTX & - & $\mathrm{R}$ \\
\hline
\end{tabular}

ADA, adalimumab; DMARDs, disease-modifying antirheumatic drugs; ETA, etanercept; INF, infliximab; PRED, prednisone; MTX, methotrexate; $N R$, nonresponder; $R$, responder.

clinical status of patients (responder versus nonresponder) would relate to the CD4pos T-cell immunity examined through the CMV-specific CD4pos population. Because the anti-CMV CD4pos T-cell response is enriched in the CD28 $8^{\text {neg }}$ compartment $[17,26]$, we measured the percentage of IFN- $\gamma^{\text {pos }} \mathrm{CD} 4$ pos $\mathrm{T}$ cells within the $\mathrm{CD} 28^{\text {neg }}$ compartment after exposure to CMV Ags. As expected, Figure 3 shows that the CD4pos $\mathrm{T}$ cells specific for IFN$\gamma^{\text {pos }}$ were greatly enriched in the CD28neg population (4.7\% versus $0.35 \%$ in the total CD4pos population), but, again, no significant statistical difference was observed between time points and between responders and nonresponders.

We next evaluated the percentage of total CD28 neg among the CD4pos T-cell population during anti-TNF- $\alpha$ treatments (Figure 4). The percentage of $\mathrm{CD} 28^{\text {neg }} \mathrm{CD} 4$ pos cells in RA patients was similar to that observed previously by Schmidt et al. [27,29]. As previously reported [35], this percentage did not increase over the course of the treatment $(6.1 \%, 6.5 \%$, and $5.2 \%$, respectively, at day 0 , week 6, and week 12) (Figure 4). However, contrary to what has been reported [35], no increase of the CD28 intensity was observed in the responders group (data not shown). Although the percentages were higher in the responders population, this difference was not statistically significant at any time point: $P=0.2278$ at day $0 ; P=$ 0.056 at week $6 ; P=0.1775$ at week 12 .

\section{Discussion}

In this work, we analyzed the CD4pos T-cell response to CMV total Ags to evaluate the consequences of treatments with anti-TNF agents on the viral immune mem- 

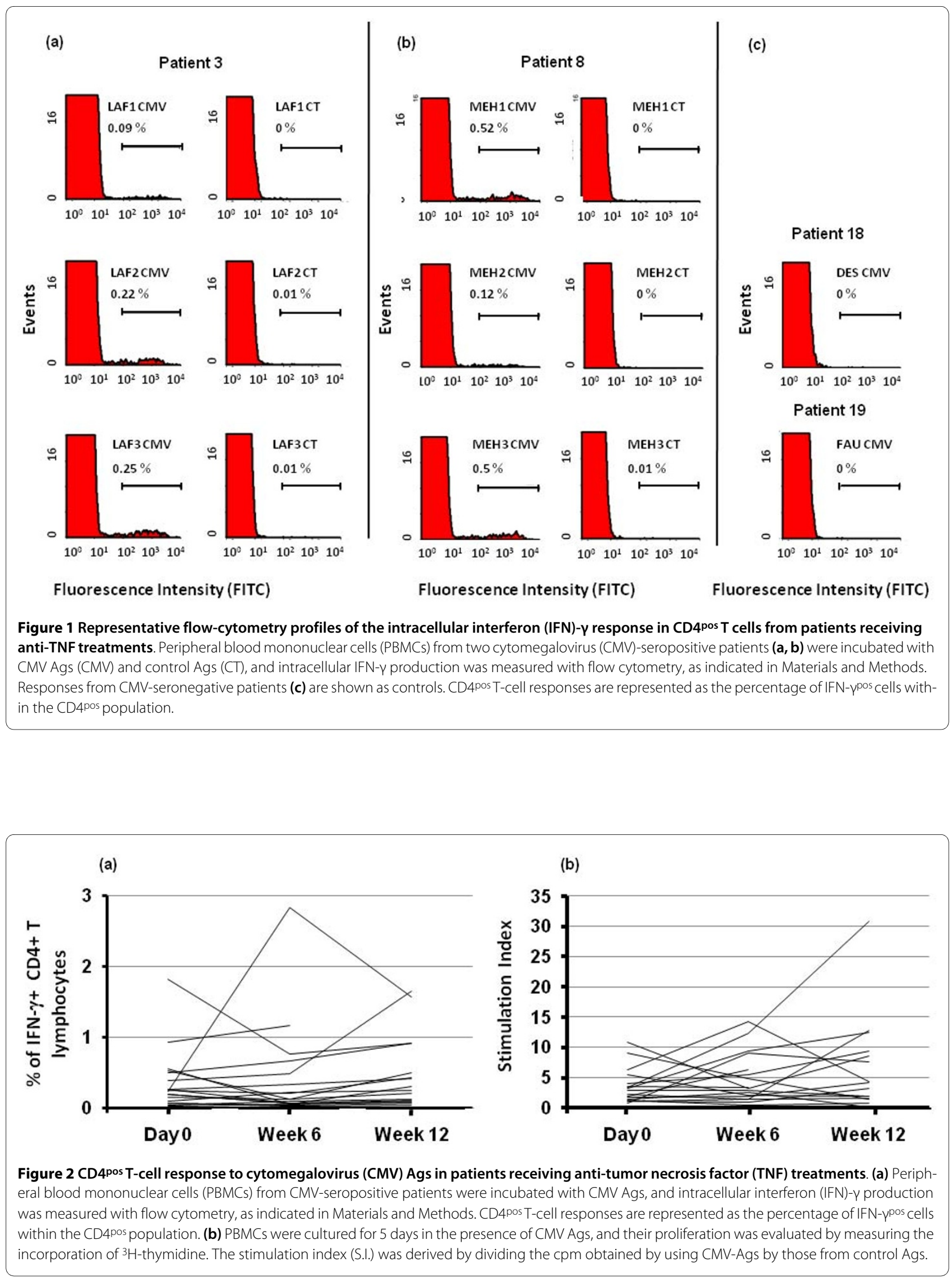


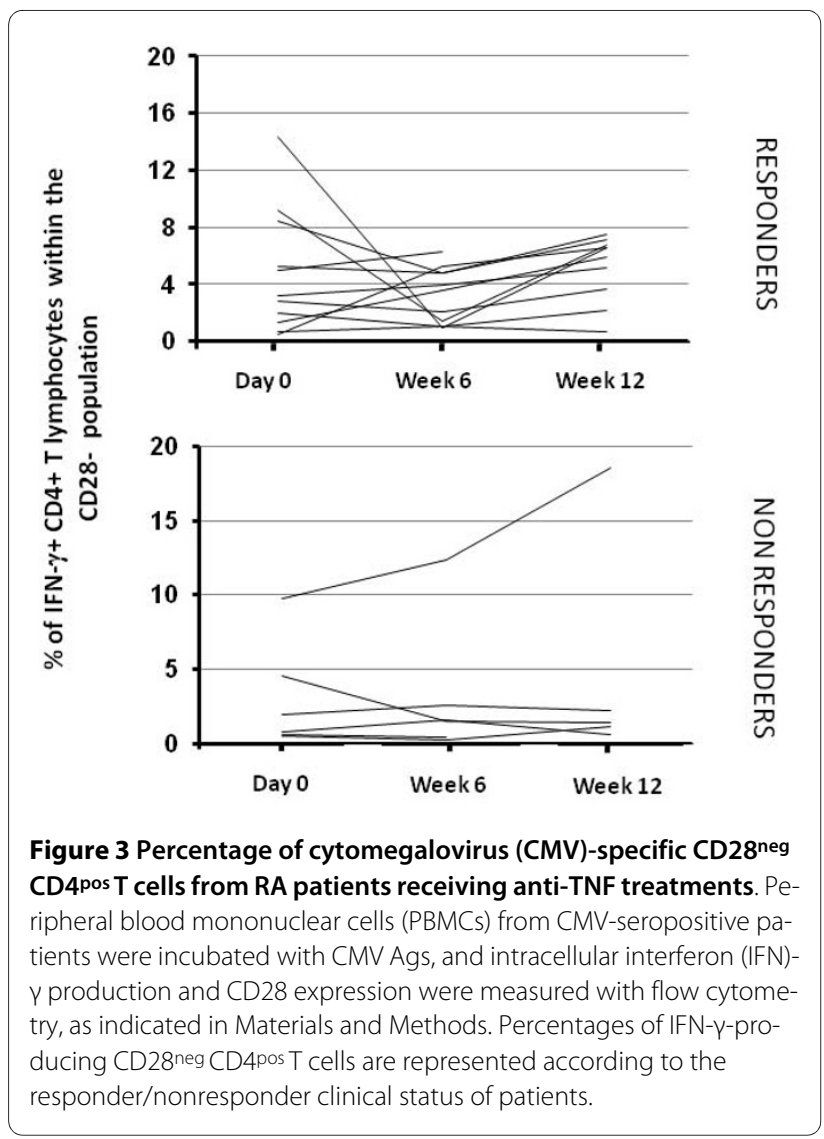

ory response. We observed that the CD4pos T-cell response toward CMV Ags was not altered by anti-TNF antagonists, whether soluble receptor or antibodies.

Production of IFN- $\gamma$ is a marker and potent effecter of the antiviral response, especially against CMV [21,25]. In this work, total CMV Ags were used to monitor the global CD4pos immune response through the IFN- $\gamma$ production. It appeared that the immunity to viral CMV Ags was conserved during the course of the treatment. Primary infections by CMV are accompanied by the appearance of a high response and frequency of specific CD4pos $\mathrm{T}$ cells, which are maintained durably $[18,21,36]$. The absence of modification of the anti-CMV CD4pos T-cell response in most patients and slight variations in some others observed in our present study are similar to those in previous studies in normal blood donors regarding proliferation [18] and cytokine production by flow cytometry in transplant recipients [37] and HIV patients [36]. Contrary to the anti-mycobacteria CD8pos T-cell response [9], the frequency of anti-CMV CD4pos T cells was not impaired by anti-TNF treatments. Our data suggest that the anti-CMV response is sufficient to control the latent CMV infection during the course of the antiTNF treatments.

As observed in previous reports $[17,26]$, the percentages of CMV-specific CD4pos T cells in the CD28 ${ }^{\text {neg }}$ popu-

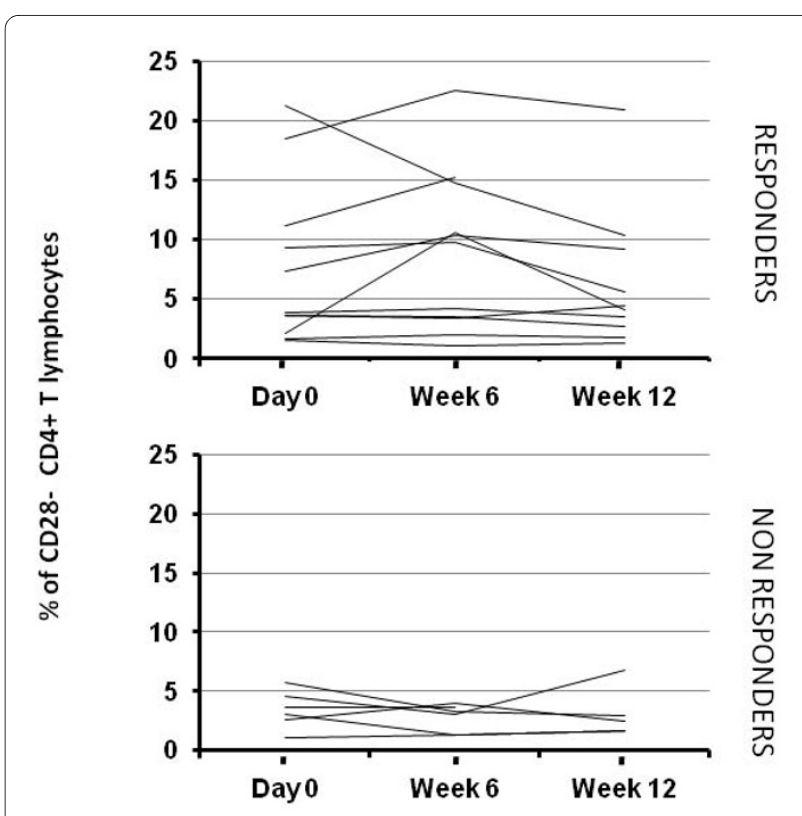

Figure 4 Percentage of total $C D 28^{\text {neg }} C D 4$ pos $T$ cells from antiTNF-treated RA patients over time in patients receiving anti-tumor necrosis factor (TNF) treatments. Peripheral blood mononuclear cells (PBMCs) from RA patients were stained for CD28 and CD4, examined with flow cytometry, and the percentages were represented according to the responder/nonresponder clinical status of patients.

lation were high, as compared with those observed in the general $\mathrm{CD} 4$ pos $\mathrm{T}$ cell population. We observed that those percentages, obtained by using infected cell lysates, were lower than those observed when using synthetic peptides [17]. However, they were within the range of and in accordance with those reported with whole-cell lysate [17]. Thus, all peptides may not be available as epitopes through processing of total CMV Ags by APC.

The high proportion of CMV-specific CD4pos $\mathrm{T}$ cells in the $C D 28^{\text {neg }}$ population was reported earlier $[17,26]$, but had not been studied in RA. The percentage of CD28 ${ }^{\text {neg }}$ CD4pos $\mathrm{T}$ cells observed in the present study was similar to that observed by Schmidt et al. [27] in RA patients.

However, the scope of this present study was not to compare the percentage of $\mathrm{CD} 28^{\text {neg }} \mathrm{CD} 4$ pos $\mathrm{T}$ cells in the normal population and RA patients. We followed the proportion of CD28 ${ }^{\text {neg }} C D 4$ pos $T$ cells during the course of anti-TNF treatment. Despite the neutralization of TNF- $\alpha$, the percentage of $C D 28^{\text {neg }} C D 4^{\text {pos }}$ cells did not vary during the course of anti-TNF treatment in our study. The role of $\mathrm{CD} 28^{\text {neg }} \mathrm{CD} 44^{\text {pos }}$ cells in RA is not elucidated, but it has been suggested that they do not play an aggressive role in autoimmunity and may not play a specific role in RA [34].

Hyporesponsiveness was reported in RA patients in $\mathrm{T}$ cells from synovial fluid [30]. The significant response of $\mathrm{CD} 4{ }^{\text {pos }} \mathrm{T}$ cells from peripheral blood at day 0 of treat- 
ment and the relatively stable anti-CMV response over the course of treatment in our current study suggest (a) that anergy to anti-CMV Ags, if any, was not a prominent feature of RA patients; and (b) that anti-TNF treatments did not restore function from CD4pos $\mathrm{T}$ cells putatively engaged in anergy or in TNF- $\alpha$-induced hyporesponsiveness [29].

Several studies have analyzed the in vitro responses to pathogens that are at risk in RA patients treated with anti-TNF. The ex vivo anti-mycobacteria IFN- $\gamma$ response was found to be impaired by infliximab and adalimumab [8] and was in accordance with the risk of reactivation of tuberculosis, especially with antibodies [38]. The situation regarding the antiviral immunity may be more complex and has been less explored. Although HBV has been described to reactivate on anti-TNF treatment [3], longterm safety of TNF blockers requires longer follow-up regarding $\mathrm{HCV}[3,39]$.

Regarding EBV, a member of the herpes family, the risk of lymphoma has been debated [3]. The anti-EBV response was found to be maintained [13], suggesting that no short-term (3 month) defect in EBV-immune surveillance occurs in patients receiving MTX or anti-TNF drugs.

A risk of varicella-zoster virus infection, another member of the herpes virus family, may be present, as reported by Strangfeld et al. [14]. However, in vitro studies of the CD4pos T-cell response against varicella-zoster Ags have not been performed. Several cases of CMV infection have been reported during the course of anti-TNF treatments $[3,40,41]$. However, because patients received concomitant immunosuppressive treatments, it is difficult to establish a link between anti-TNF treatment and reactivation of CMV.

Our present data argue in favor of the maintenance of anti-CMV immunity during anti-TNF treatments. This is of importance in light of previous observations that TNF$\alpha$ is an important component of the anti-CMV control in vitro [25,42]. Our current study and former published reports $[8,13]$ suggest that in vitro responses to viral proteins or peptides are of help to identify risks of viral infection in patients treated with anti-TNF. In addition, the conservation of anti-CMV CD4pos $\mathrm{T}$ cell immunity during anti-TNF treatment suggests that vaccinations can be envisaged during treatment by anti-TNF. However, until safety data are available, live attenuated virus vaccines should be contraindicated in RA patients.

\section{Conclusions}

We have used the anti-CMV CD4pos T-cell response as a test for the integrity of the antiviral immune response during anti-TNF treatments. Our data show that the antiCMV CD4pos T-cell IFN- $\gamma$ and proliferative responses are maintained during anti-TNF treatments. No modifica- tion of the percentage of specific or total CD28 $8^{\text {neg }} \mathrm{CD} 4$ pos $\mathrm{T}$ cells during anti-TNF treatments was observed. Because CD4pos $\mathrm{T}$ cells are an important component of the anti-CMV immunity, our observations suggest that CMV infections are well controlled during anti-TNF treatments and bring new insight into the current knowledge of the risks of infection in patients treated with antiTNF- $\alpha$ biotherapies.

\section{Abbreviations}

Ags: antigens; CMV: cytomegalovirus; RA: rheumatoid arthritis.

\section{Competing interests}

The authors declare that they have no competing interests.

\section{Authors' contributions}

$J-L D, A C O$, and ACa designed the study. DN participated in the design of the study and performed the statistical analysis. J-LD and J-FB performed the experiments. J-FB, BJ, ACo, and ACa enrolled patients. J-LD, ACo, and ACa wrote the manuscript. All authors helped to draft the manuscript. All authors read and approved the final manuscript.

\section{Acknowledgements}

This work was supported by Société Française de Rhumatologie and University Paul Sabatier Toulouse III. We thank Michel Baron for excellent technical assistance. We thank the flow-cytometry facilities (Dr. F-E L'Faqihi-Olive of IFR150 (Toulouse, France) and M.-H. Cerato) for help with the collection of data.

\section{Author Details}

1JE 2510, University Paul Sabatier Toulouse III. France, IFR 150, CPTP, Bâtiment C, CHU Purpan, 1, place Baylac, 31300 Toulouse, France, ${ }^{2}$ Centre of Rheumatology, CHU Purpan, 1, place Baylac, BP 3028, 31024 Toulouse, France and 3INSERM U558, Toulouse, Faculté de Médecine, 37, allées Jules Guesde, 31073 Toulouse Cedex, France

Received: 16 March 2010 Revised: 26 May 2010 Accepted: 15 July 2010 Published: 15 July 2010

\section{References}

1. Ruderman EM: Current and future pharmaceutical therapy for rheumatoid arthritis. Curr Pharm Des 2005, 11:671-684.

2. Smolen JS, Steiner G: Therapeutic strategies for rheumatoid arthritis. Nat Rev Drug Discov 2003, 2:473-488.

3. Domm S, Cinatl J, Mrowietz U: The impact of treatment with tumour necrosis factor-alpha antagonists on the course of chronic viral infections: a review of the literature. Br J Dermato/ 2008, 159:1217-1228.

4. Camussi G, Albano E, Tetta C, Bussolino F: The molecular action of tumor necrosis factor-alpha. Eur J Biochem 1991, 202:3-14.

5. Kindler V, Sappino AP, Grau GE, Piguet PF, Vassalli P: The inducing role of tumor necrosis factor in the development of bactericidal granulomas during BCG infection. Cell 1989, 56:731-740.

6. Gomez-Reino JJ, Carmona L, Valverde VR, Mola EM, Montero MD: Treatment of rheumatoid arthritis with tumor necrosis factor inhibitors may predispose to significant increase in tuberculosis risk: a multicenter active-surveillance report. Arthritis Rheum 2003, 48:2122-2127.

7. Keane J, Gershon S, Wise RP, Mirabile-Levens E, Kasznica J, Schwieterman WD, Siegel JN, Braun MM: Tuberculosis associated with infliximab, a tumor necrosis factor alpha-neutralizing agent. N Engl J Med 2001, 345:1098-1104.

8. Hamdi H, Mariette X, Godot V, Weldingh K, Hamid AM, Prejean MV, Baron G, Lemann M, Puechal X, Breban M, Berenbaum F, Delchier JC, Flipo RM, Dautzenberg B, Salmon D, Humbert M, Emilie D: Inhibition of antituberculosis T-lymphocyte function with tumour necrosis factor antagonists. Arthritis Res Ther 2006, 8:R114.

9. Bruns H, Meinken C, Schauenberg P, Harter G, Kern P, Modlin RL, Antoni C, Stenger S: Anti-TNF immunotherapy reduces CD8+ T cell-mediated antimicrobial activity against Mycobacterium tuberculosis in humans. $J$ Clin Invest 2009, 119:1167-1177. 
10. Wolfe F, Michaud K: Lymphoma in rheumatoid arthritis: the effect of methotrexate and anti-tumor necrosis factor therapy in 18,572 patients. Arthritis Rheum 2004, 50:1740-1751

11. Geborek P, Bladstrom A, Turesson C, Gulfe A, Petersson IF, Saxne T, Olsson $H$, Jacobsson LT: Tumour necrosis factor blockers do not increase overall tumour risk in patients with rheumatoid arthritis, but may be associated with an increased risk of lymphomas. Ann Rheum Dis 2005, 64:699-703.

12. Baecklund E, Iliadou A, Askling J, Ekbom A, Backlin C, Granath F, Catrina Al, Rosenquist R, Feltelius N, Sundstrom C, Klareskog L: Association of chronic inflammation, not its treatment, with increased lymphoma risk in rheumatoid arthritis. Arthritis Rheum 2006, 54:692-701.

13. Miceli-Richard C, Gestermann N, Amiel C, Sellam J, Ittah M, Pavy S, Urrutia A, Girauld I, Carcelain G, Venet A, Mariette X: Effect of methotrexate and anti-TNF on Epstein-Barr virus T-cell response and viral load in patients with rheumatoid arthritis or spondylarthropathies. Arthritis Res Ther 2009, 11:R77

14. Strangfeld A, Listing J, Herzer P, Liebhaber A, Rockwitz K, Richter C, Zink A: Risk of herpes zoster in patients with rheumatoid arthritis treated with anti-TNF-alpha agents. JAMA 2009, 301:737-744.

15. Sissons JG, Carmichael AJ, McKinney N, Sinclair JH, Wills MR: Human cytomegalovirus and immunopathology. Springer Semin Immunopathol 2002, 24:169-185.

16. Vaz-Santiago J, Lule J, Rohrlich P, Jacquier C, Gibert N, Le Roy E, Betbeder $D$, Davignon JL, Davrinche C: Ex vivo stimulation and expansion of both CD4(+) and CD8(+) T cells from peripheral blood mononuclear cells of human cytomegalovirus-seropositive blood donors by using a soluble recombinant chimeric protein, IE1-pp65. J Virol 2001, 75:7840-7847.

17. Sylwester AW, Mitchell BL, Edgar JB, Taormina C, Pelte C, Ruchti F, Sleath PR, Grabstein KH, Hosken NA, Kern F, Nelson JA, Picker LJ: Broadly targeted human cytomegalovirus-specific CD4+ and CD8+ T cells dominate the memory compartments of exposed subjects. J Exp Med 2005, 202:673-685.

18. Davignon $\mathrm{J}$, , Clement D, Alriquet J, Michelson S, Davrinche C: Analysis of the proliferative $T$ cell response to human cytomegalovirus major immediate-early protein (IE1): phenotype, frequency and variability. Scand J Immunol 1995, 41:247-255

19. Prieur E, Betbeder D, Niedergang F, Major M, Alcover A, Davignon JL, Davrinche C: Combination of human cytomegalovirus recombinant immediate-early protein (IE1) with $80 \mathrm{~nm}$ cationic biovectors: protection from proteolysis and potentiation of presentation to CD4+ T-cell clones in vitro. Vaccine 1996, 14:511-520.

20. Vescovini R, Biasini C, Fagnoni FF, Telera AR, Zanlari L, Pedrazzoni M, Bucci $L$, Monti D, Medici MC, Chezzi C, Franceschi C, Sansoni P: Massive load of functional effector CD4+ and CD8+ T cells against cytomegalovirus in very old subjects. J Immunol 2007, 179:4283-4291.

21. Gamadia LE, Remmerswaal EB, Weel JF, Bemelman F, van Lier RA, Ten Berge IJ: Primary immune responses to human CMV: a critical role for IFN-gamma-producing CD4+ T cells in protection against CMV disease. Blood 2003, 101:2686-2692.

22. Le Roy E, Baron M, Faigle W, Clement D, Lewinsohn DM, Streblow DN, Nelson JA, Amigorena S, Davignon JL: Infection of APC by human cytomegalovirus controlled through recognition of endogenous nuclear immediate early protein 1 by specific CD4(+) T lymphocytes. J Immunol 2002, 169:1293-1301.

23. Walter EA, Greenberg PD, Gilbert MJ, Finch RJ, Watanabe KS, Thomas ED, Riddell SR: Reconstitution of cellular immunity against cytomegalovirus in recipients of allogeneic bone marrow by transfer of T-cell clones from the donor. NEngl J Med 1995, 333:1038-1044

24. Einsele H, Roosnek E, Rufer N, Sinzger C, Riegler S, Loffler J, Grigoleit U, Moris A, Rammensee HG, Kanz L, Kleihauer A, Frank F, Jahn G, Hebart H: Infusion of cytomegalovirus (CMV)-specific T cells for the treatment of CMV infection not responding to antiviral chemotherapy. Blood 2002, 99:3916-3922.

25. Davignon JL, Castanie P, Yorke JA, Gautier N, Clement D, Davrinche C: Anti-human cytomegalovirus activity of cytokines produced by CD4+ T-cell clones specifically activated by IE1 peptides in vitro. J Virol 1996, 70:2162-2169

26. Amyes E, Hatton C, Montamat-Sicotte D, Gudgeon N, Rickinson AB, McMichael AJ, Callan MF: Characterization of the CD4+ T cell response to Epstein-Barr virus during primary and persistent infection. J Exp Med 2003, 198:903-911.
27. Schmidt D, Goronzy JJ, Weyand CM: CD4+ CD7- CD28- T cells are expanded in rheumatoid arthritis and are characterized by autoreactivity. J Clin Invest 1996, 97:2027-2037.

28. Bryl E, Vallejo AN, Weyand CM, Goronzy JJ: Down-regulation of CD28 expression by TNF-alpha. J Immuno/ 2001, 167:3231-3238.

29. Cope AP, Londei M, Chu NR, Cohen SB, Elliott MJ, Brennan FM, Maini RN Feldmann M: Chronic exposure to tumor necrosis factor (TNF) in vitro impairs the activation of T cells through the T cell receptor/CD3 complex; reversal in vivo by anti-TNF antibodies in patients with rheumatoid arthritis. J Clin Invest 1994, 94:749-760.

30. Romagnoli P, Strahan D, Pelosi M, Cantagrel A, van Meerwijk JP: A potential role for protein tyrosine kinase $\mathrm{p} 56$ (lck) in rheumatoid arthritis synovial fluid T lymphocyte hyporesponsiveness. Int Immunol 2001, 13:305-312

31. Prevoo ML, van 't Hof MA, Kuper $H H$, van Leeuwen MA, van de Putte LB, van Riel PL: Modified disease activity scores that include twenty-eightjoint counts: development and validation in a prospective longitudinal study of patients with rheumatoid arthritis. Arthritis Rheum 1995, 38:44-48.

32. van Gestel AM, Prevoo ML, van 't Hof MA, van Rijswijk MH, van de Putte LB, van Riel PL: Development and validation of the European League Against Rheumatism response criteria for rheumatoid arthritis: comparison with the preliminary American College of Rheumatology and the World Health Organization/International League Against Rheumatism Criteria. Arthritis Rheum 1996, 39:34-40.

33. Choy EH, Smith C, Dore CJ, Scott DL: A meta-analysis of the efficacy and toxicity of combining disease-modifying anti-rheumatic drugs in rheumatoid arthritis based on patient withdrawal. Rheumatology (Oxford) 2005, 44:1414-1421.

34. Thewissen M, Somers V, Hellings N, Fraussen J, Damoiseaux J, Stinissen P CD4+CD28null T cells in autoimmune disease: pathogenic features and decreased susceptibility to immunoregulation. J Immunol 2007 179:6514-6523.

35. Bryl E, Vallejo AN, Matteson EL, Witkowski JM, Weyand CM, Goronzy JJ: Modulation of CD28 expression with anti-tumor necrosis factor alpha therapy in rheumatoid arthritis. Arthritis Rheum 2005, 52:2996-3003.

36. Komanduri KV, Donahoe SM, Moretto WJ, Schmidt DK, Gillespie G, Ogg GS, Roederer M, Nixon DF, McCune JM: Direct measurement of CD4+ and CD8+ T-cell responses to CMV in HIV-1-infected subjects. Virology 2001, 279:459-470.

37. Widmann T, Sester U, Gartner BC, Schubert J, Pfreundschuh M, Kohler H, Sester M: Levels of CMV specific CD4 T cells are dynamic and correlate with CMV viremia after allogeneic stem cell transplantation. PLoS One 2008, 3:e3634

38. Tubach F, Salmon D, Ravaud P, Allanore Y, Goupille P, Breban M, Pallot Prades B, Pouplin S, Sacchi A, Chichemanian RM, Bretagne S, Emilie D, Lemann M, Lorthololary $\mathrm{O}$, Mariette X: Risk of tuberculosis is higher with anti-tumor necrosis factor monoclonal antibody therapy than with soluble tumor necrosis factor receptor therapy: the three-year prospective French research axed on tolerance of biotherapies registry. Arthritis Rheum 2009, 60:1884-1894.

39. Nathan DM, Angus PW, Gibson PR: Hepatitis B and C virus infections and anti-tumor necrosis factor-alpha therapy: guidelines for clinical approach. J Gastroenterol Hepatol 2006, 21:1366-1371.

40. Helbling D, Breitbach TH, Krause M: Disseminated cytomegalovirus infection in Crohn's disease following anti-tumour necrosis factor therapy. Eur J Gastroenterol Hepato/ 2002, 14:1393-1395.

41. Mizuta M, Schuster MG: Cytomegalovirus hepatitis associated with use of anti-tumor necrosis factor-alpha antibody. Clin Infect Dis 2005, 40:1071-1072.

42. Allan-Yorke J, Record M, de Preval C, Davrinche C, Davignon JL: Distinct pathways for tumor necrosis factor alpha and ceramides in human cytomegalovirus infection. J Virol 1998, 72:2316-2322.

doi: $10.1186 / \operatorname{ar} 3083$

Cite this article as: Davignon et al., Maintenance of cytomegalovirus-specific CD4pos T-cell response in rheumatoid arthritis patients receiving antitumor necrosis factor treatments Arthritis Research \& Therapy 2010, 12:R142 